\title{
HOW DO FIRMS' ACTIONS IMPACT GREEN SCEPTICISM? THE EFFECTS OF GREEN BRAND ASSOCIATIONS, GREEN BRAND EQUITY AND GREENWASHING
}

\author{
DOI: 10.17261/Pressacademia.2019.1172 \\ JMML-V.6-ISS.4-2019(1)-p.204-211 \\ Ulun Akturan ${ }^{1}$, Nuray Tezcan ${ }^{2}$ \\ ${ }^{1}$ Galatasaray University, Business Administration Department, Istanbul, Turkey. \\ uakturan@gsu.edu.tr, ORCID: 0000-0002-3460-7244 \\ ${ }^{2}$ Halic University, Business Informatics Department, Istanbul, Turkey. \\ nuraytezcan@hotmail.com, ORCID: 0000-0002-3184-7330
}

Date Received: November 6, 2019

Date Accepted: December 18, 2019

To cite this document

Akturan, U., Tezcan, N. (2019), How do firms' actions impact green scepticism? The effects of green brand associations, green brand equity and greenwashing. Journal of Management, Marketing and Logistics (JMML), V.6(4),p.204-211.

Permemant link to this document: http://doi.org/10.17261/Pressacademia.2019.1172

Copyright: Published by PressAcademia and limited licenced re-use rights only.

\begin{abstract}
Purpose- This study aims to explore how greenwashing, green brand equity and green brand associations affect green skepticism.

Methodology- In the study, survey method was used to collect the data. After eliminating unreliable questionnaires, final sample size consists of 400 respondents. To check the reliability and the construct validity of the scales, Cronbach's Alpha coefficient and Exploratory Factor Analysis (EFA) was run, and to affirm the convergent and discriminant validity, Confirmatory Factor Analysis (CFA) was used. In order to test the research hypothesis, Structural Equation Modeling (SEM) was conducted.

Findings- According to the results, it was found that green skepticism is positively affected by greenwashing, while negatively affected by green brand associations and green brand equity.

Conclusion- Greenwashing positively affects green skepticism, while there is a positive relationship between green brand associations, green brand equity and green skepticism.
\end{abstract}

Keywords: Green scepticism, greenwashing, green brand equity, green brand associations, structural equation modelling.

JEL Codes: M31, C83, L21

\section{INTRODUCTION}

During the past few decades, increases in environmental concern enforced companies to develop green strategies almost in every business functions such as marketing, production, supply chain management etc. Today, there is a huge amount of green products offered in the markets (Leonidou and Skarmeas, 2017). By that means, there is also increasing consumer awareness in relation with the firms' environmental actions (Wei et al., 2017). On the other hand, there is also a growing concern about the green misleading communication done by companies to increase their green perception (Parguel et al. 2011). Corporates' malfeasances and irresponsible environmental behaviors are hold responsible for the increases in scepticism towards green actions (Mohr et al.1998; Obermiller et al. 2005).

Green skepticism is an important issue not only for consumers, but also for companies, investors, governments, and society in general (Leonidou and Skarmeas, 2017). Because as scepticism increases, consumers' intentions to buy green products decreases (Albayrak et al. 2011). In addition to that, skepticism also causes diminishes on the positive impact of green communication (do Paco and Reis, 2012). In the long turn, those may cause erosions in the markets in which companies invest on eco-friendly products (Leonidou and Skarmeas, 2017). Furthermore, green skepticism drives consumers to seek more information and fosters negative word of mouth (Leonidou and Skarmeas, 2017). More importantly, green skepticism lowers customers' environmental knowledge and environmental concern (Goh and Balaji, 2016), and therefore may drive erosions in the society regarding sustainability. 
There is an extant literature on green marketing however green scepticism is an understudied concept (Leonidou and Skarmeas, 2017; Goh and Balaji, 2016). The literature generally focuses upon green ad scepticism (Shrum et al., 1995; Matthes and Wonneberger, 2014; Wei et al., 2017) and how marketing communication is related with scepticism (Raska and Shaw, 2012); skepticism towards environmental issues such as climate change (Pelham, 2018), and the relationship between consumers' environment related attitudes and skepticism (Goh and Balaji, 2006; Rahman et al., 2015). Yet, how firms' branding-related actions impact green scepticism has escaped adequate research attention. On that ground, this study aims to fulfil that gap by exploring how greenwashing, green brand equity and green brand associations affect green scepticism.

\section{LITERATURE REVIEW}

\subsection{Green Scepticism and Greenwashing}

Scepticism is defined as "a person's tendency to distrust or disbelieve" (Romani et al., 2016 p.255). It may either be considered as enduring, and therefore as a personality trait (Obermiller and Spangenberg 1998) or as situational, and therefore contextdependent (Singh et al. 2009; Pirsch et al. 2007). Situational scepticism is independent from one's trait but depends on the context (Rahmani et al., 2016). Scepticism is studied across different disciplines such as psychology, sociology, politics and philosophy (Skarmeas and Leonidou, 2013). In the business context, consumers' scepticism in relation with advertising, promotion, public relations, and consumer social responsibility (CSR) and green marketing were studied.

Consumers evaluate the messages and actions of the firms and in some point they may develop scepticism as a result of their evaluations (Friestad and Wright 1994). Green scepticism is a situational scepticism and refers to doubting or disbelieving environmental claims made by the firms (Goh and Balaji, 2016). On that basis, it is affected by firms' communications and actions. Prior research stated that there are several drivers causing green scepticism. Leonidou and Skarmeas (2017) indicate that consumers classify firms' actions either as intrinsic (such as value-driven motives) or extrinsic motives (such as stakeholder-driven motives). Intrinsic motives are selfless actions to do good while extrinsic motives are related with increasing one's own welfare (Parguel et al., 2011). In their study, Leonidou and Skarmeas (2017) verified that when consumers perceive that the green talk and green walk achieved by the firm is a selfless action, then their scepticism decreases. Green scepticism negatively affects credibility of the green ad. Consumers, who are highly sceptical, are biased towards information claims and therefore they do not trust the arguments in the ads. On that ground, they develop a negative attitude towards green products, which affects green purchase intention and behavior negatively (Wei et al., 2017; Ulusoy and Barretta, 2016). Therefore it was hypothesized that;

H1: Greenwashing positively affects green scepticism.

\subsection{The Green Brand Equity}

All of the marketing activities, either done successfully or unsuccessfully, add a value to the brand and as a result generate a consumer response, which is conceptualized as brand equity (Aaker, 1991; Keller, 1993). Brand equity is defined as "consumers' different response between a focal brand and an unbranded product when both have the same level of marketing stimuli and product attributes" (Yoo and Donthu, $2001 \mathrm{p}$. 1). The difference in consumer response is derived from the marketing activities. In relation with that conceptualization of brand equity, Chen (2010, p. 310) defined green brand equity as "a set of brand assets and liabilities about green commitments and environmental concerns linked to a brand, its name and symbol that add to or subtract from the value provided by a product or service". Today, green brand equity is an important tool to achieve competitive advantage since it enables companies to strongly position their products in green markets (Butt et al., 2017).

The main focus in the green marketing literature was to determine the antecedents of green brand equity (Kang and Hur, 2012; Chang and Chen, 2014; Ng et al, 2014). The outcomes of green brand equity are understudied. However, previous literature for conventional marketing confirms that brand equity positively affects marketing success (Ambler, 1997; Simon and Sullivan, 1993; Lane and Jacobson, 1995), future profits and long-term cash flow (Srivastava and Shocker, 1991), and consumers' willingness to pay more (Keller, 1993).

Green brand equity derives from the green marketing activities and generates a positive response in the market. Almost each marketing activity affects brand equity, but especially activities that lead to perceived quality, positive brand image, brand loyalty, positive associations are crucial, since those are defined as the main dimensions of brand equity, along with the tangible assets of the brand (Aaker, 1997). On that ground, strong green brand equity is a sum of the positive perceptions of quality, image, and associations. Therefore, it was hypothesized that;

H2: Green brand equity negatively affects green scepticism. 


\subsection{The Green Brand Associations}

Brand associations are "the informational nodes linked to the brand node in memory and contain the meaning of the brand for consumers" (Belen del Rio et al., 2001). The brand attributes, benefits and attitudes are stored in the consumers' minds and generate an information source (Keller, 1998). Brand associations can be anything recorded into the category of "brand's assets and liabilities" in the memory (Aaker, 1991). Brand associations are not only used by consumers to organize and retrieve information about the brands but also used by the marketers to differentiate and extend brand, to create positive attitudes and feelings toward brands (Low and Lamb, 2000). Strong, positive, and unique associations fortify a brand and increase brand equity (Keller, 2001). Moreover, when consumers hold strong and positive associations in their mind their perceptions about the disbelief of the firms' green actions diminishes. Therefore it was hypothesized that;

H3: Green brand associations negatively affect green scepticism.

\section{DATA AND METHODOLOGY}

Data was collected by using survey method, and 400 consumers were interviewed face-to-face by the interviewers. The sociodemographics of the sample is as follows: Gender (52\% female, $48 \%$ male), age group: 18-25 (26\%); $26-35$ (40\%); 36-45 (17\%), income level: 400-1350 USD (62\%). As a subject to study, well-known refrigerator brand, which positions itself as green, was used. Green scepticism was adopted from Goh and Balaji (2016) and measured by four items, green brand equity was adopted from Chen and Chang (2012) and measured by four items, greenwashing was adopted from Chen and Chang (2013) and measured by five items, and green brand associations was adopted from Chang and Chen (2014) and measured by four items. Five-point Likert scale rating from strongly agreement to strongly disagreement was used in scaling. The research model used in the study is shown in Figure 1.

Figure 1: Research Model

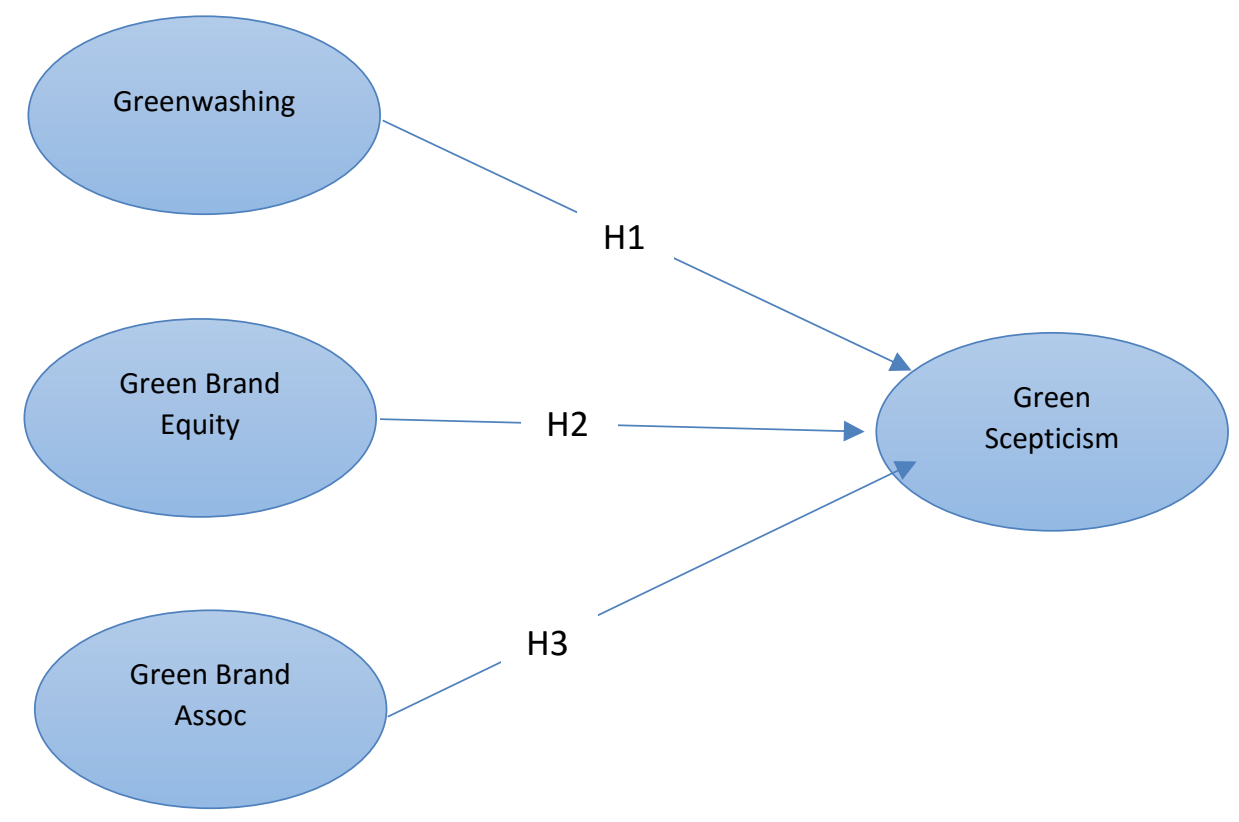

As it is seen in Figure 1 above, this study explores the effects of greenwashing, green brand equity and green brand associations on green skepticism. In the study it was hypothesized that green washing positively affects green skepticism while green brand equity and green brand associations have negative impacts upon green skepticism.

\section{FINDINGS AND DISCUSSIONS}

\subsection{Reliability and Validity Check}

The reliability and the validity of the scales were checked by running Cronbach's Alpha coefficient and Exploratory Factor Analysis (EFA). Table 1 displays Cronbach's Alpha values and explained variance by each variable. 
Table 1: The Cronbach's Alpha Values and Explained Variance

\begin{tabular}{lccccc}
\hline Constructs & \# of items & $\begin{array}{c}\text { Cronbach's } \\
\text { Alpha }\end{array}$ & $\begin{array}{c}\text { KMO } \\
\text { Values }\end{array}$ & $\begin{array}{c}\text { Bartlett test of } \\
\text { sphericity sig. }\end{array}$ & $\begin{array}{c}\text { Variance Explained } \\
\text { (\%) }\end{array}$ \\
\hline Green Scepticism & $3(4)^{*}$ & .794 & .663 & .000 & 71.0 \\
Greenwashing & 5 & .869 & .840 & .000 & 65.8 \\
Green Brand Equity & 4 & .849 & .765 & .000 & 64.9 \\
Green Brand Associations & $4(5)^{*}$ & .795 & .767 & .000 & 62.7 \\
\hline
\end{tabular}

*One item deleted to increase the internal consistency.

As it is seen in Table 1, Cronbach's Alpha values are high above the minimum required level of .70 after deleting one item from green associations scale and green skepticism scale. In order to test the validity of the scales, EFA with principal component method was run. First, Keiser-Meyer-Olkin of sampling adequacy (KMO) and Bartlett test of sphericity for each construct were checked to assure the appropriateness of EFA. KMO values are high above the minimum required level .50 and the Bartlett test of sphericity for each construct is significant. As a result of EFA, it was found that all the constructs explains at least 66 per cent variance.

Moreover, Confirmatory Factor Analysis (CFA) was conducted to affirm the convergent and discriminant validity. At first, the goodness-of-fit between the data and the model was tested. The fitness measures provide the required levels (CMIN/df= $2.280, \mathrm{GFI}=.953, \mathrm{IFI}=.966, \mathrm{TLI}=.954, \mathrm{CFI}=.966$, and RMSEA $=.051)$. In order to assess convergent validity, factor loadings, composite reliability (CR) and average variance extracted (AVE) were examined. The literature suggest that factor loadings should be between .6 and .95, the CR should be higher than .6, and AVE values should be over .5 (Lin and Niu, 2018). The results of convergent validity test were presented in Appendix 1.

For discriminant validity, the methodology stated by Fornell and Larcker (1981) was employed. Accordingly, the AVE values and the correlations between each construct were compared. The square root of the AVE should be higher than the correlations between the variables (Butt et al., 2017). The results of discriminant validity test were given in Table 3.

Table 3: The Results of Discriminant Validity Analysis

\begin{tabular}{lrrrr}
\hline & Green Scepticism & Green Brand Equity & Green Brand Assoc. & Greenwashing \\
\hline Green Scepticism & $(.588)^{*}$ & & & \\
Green Brand Equity & $-.064^{* *}$ & $(.547)$ & & \\
Green Brand Associations & -.145 & .356 & $(.591)$ & \\
Greenwashing & .285 & -.284 & -.267 & $(.504)$ \\
\hline
\end{tabular}

* The values in the parenthesis are square root AVEs.

** Correlation values between constructs.

Note I: For every latent variable, its square root AVE value is greater than its correlation coefficient values with other variables, thus verifying discriminant validity.

\subsection{Test of Structural Relationships}

Structural Equation Modeling (SEM) with maximum likelihood estimation (MLE) was run to test the relationships among constructs. Figure 2 displays structural model of relationships.

Figure 2: Structural Model of Relationships

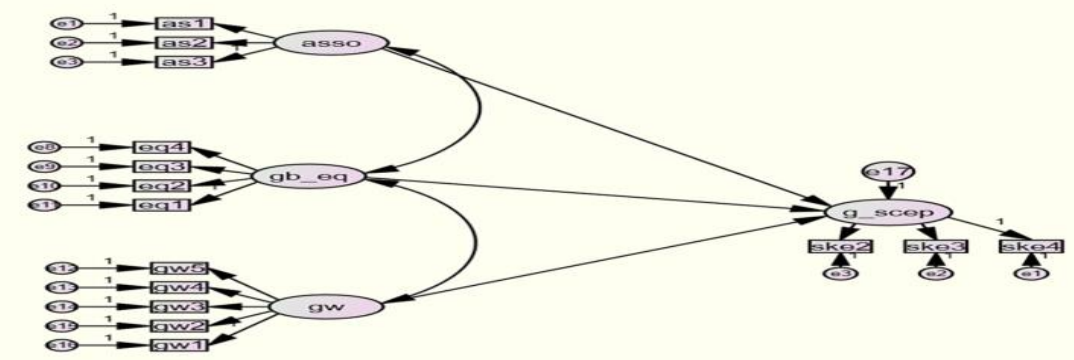


Figure 2 displays the structural paths of the research model. As it is seen in Figure 2, there are four latent variables: brand associations (asso), green brand equity (gb_eq), green washing (gw), and green scepticism (g scep). There are also 16 error terms related with the variables.

The goodness-of-fit between the data and the model was checked via various indicators. All the indicators verified good fitness between the data and the model (CMIN/df= 2.468, GFI= .950, IFI.=.963, TLI=.952, CFI=.963, and RMSEA= .054). Furthermore, Hoelter's N0.05 $=264>200$ and Hoelter's N0.01 $=290>200$ indicate the adequacy of sampling size (Schreiber et al., 2006). The results of the path analysis were presented in Table 4. Accordingly, all of the hypotheses in the research model were supported. $\mathrm{R}^{2}$ value for the model was found as .584 . In other words, the model explains approximately 60 per cent of green scepticism. Consequently, the theoretical and managerial implications of the study are discussed below.

Table 4: Hypotheses Testing of the Structural Model

\begin{tabular}{lllccccc}
\hline & & & Estimate & Std. error & t-value & sig. & \\
\hline Greenwashing & $\rightarrow$ & Green Scepticism & .371 & .065 & 5.667 & .000 & H1 Supported \\
Green Brand Equity & $\rightarrow$ & Green Scepticism & -.258 & .077 & -3.351 & .000 & H2 Supported \\
Green Brand Assoc. & $\rightarrow$ & Green Scepticism & -.147 & .072 & -2.029 & .043 & H3 Supported \\
\hline
\end{tabular}

\section{CONCLUSION}

For companies it is important to understand the green consumption behavior since there are controversial finding in the literature. The overall purpose of this study is to explore the green brand-related factors on green skepticism. More specifically, this research aims to analyze how greenwashing, green brand equity and green brand associations affect green scepticism. The data was collected from 400 consumers in Istanbul, Turkey, in which a rapidly growing environmentally sensitive market segment exist (Albayrak et al., 2013). The research hypotheses were tested by SEM. As a result it was found that greenwashing positively affects green scepticism whereas green brand associations and green brand equity have negative effects.

Skeptical consumers are vulnerable to negative information (Skarmeas and Leonidou, 2013), and therefore as misleading information increases so does the green scepticism. The greenwashing does not only affect the company, which claimed by doing greenwashing but it affects the whole green marketing industry. In fact, for the sceptical consumers, interpersonal communication is viewed as more credible than the organizational communication (Grewal, Cline, \& Davies, 2003). The companies should be aware of the greenwashing activities and take necessary action to assure that misleading actions does not add to scepticism.

In addition to greenwashing, green brand associations and green brand equity negatively affect green scepticism. On that ground companies should rely upon creating positive associations in consumers' minds and invest upon increasing the equity of their brands.

This study has some limitations that would generate further research opportunities. First, this study is executed in one emerging country hence the results should not be generalized for all the emerging countries. Besides that, one product category and one brand were used as subject to study. Therefore the results also cannot be generalized for all of the product categories and brands. Other emerging countries and other product categories should be analyzed as further research.

\section{REFERENCES}

Albayrak T., Caber M., Moutinho L. \& Ram Herstein 2011, The influence of skepticism on green purchase behavior, International Journal of Business and Social Science, Vol. 2 No. 13

Arminda Maria Finisterra do Paço \& Rosa Reis (2012) Factors Affecting Skepticism toward Green Advertising, Journal of Advertising, 41:4, 147-155, DOI: 10.1080/00913367.2012.10672463

Aaker David A. (1991), Managing Brand Equity: Capitalizing on the Valueof a Brand Name, ISBN 0-02-900101-3

Aaker, J. (1997). Dimensions of Brand Personality. Journal of Marketing Research, 34(3), 347-356. doi:10.2307/3151897 
Ambler, T. (1997), "How much of brand equity is explained by trust?", Management Decision, Vol. 35 No. 4 , pp. $283-292$. https://doi.org/10.1108/00251749710169666

Rohini Ahluwalia Robert E. Burnkrant, H. Rao Unnava 2000, Consumer Response to Negative Publicity: The Moderating Role of Commitment, Journal of Marketing Research 37(2):203-214, DOI: 10.1509/jmkr.37.2.203.18734

Butt, M. M., Mushtaq, S., Afzal, A., Khong, K. W., Ong, F. S., \& Ng, P. F. (2017). Integrating behavioural and branding perspectives to maximize green brand equity: a holistic approach. Business Strategy and the Environment, 26(4), 507-520.

Belén del Río, A., Vázquez, R. \& Iglesias, V. (2001), "The effects of brand associations on consumer response", Journal of Consumer Marketing, Vol. 18 No. 5, pp. 410-425 https://doi.org/10.1108/07363760110398808

Chen, YS. (2010) The Drivers of Green Brand Equity: Green Brand Image, Green Satisfaction, and Green Trust, Journal Business Ethics, Volume 93, Issue:2, pp. 307-319 https://doi.org/10.1007/s10551-009-0223-9

Chang, C. H. \& Chen, Y. S., (2014), "Managing green brand equity: the perspective of perceived risk theory", Quality and Quantity, Vol.48 No.3, pp.1753-1768.

Chang H.H. \& Chen S.W. (2008), The impact of online store environment cues on purchase intention, trust, and perceived risk as a mediator, Online Information Review, 32 (6) pp. 818-841

Chen, Y. \& Chang, C. (2012), "Enhance green purchase intentions", Management Decision, Vol. 50 No. 3, pp. 502-520. https://doi.org/10.1108/00251741211216250

Chen, Y. \& Chang, C. (2013), "Towards green trust", Management Decision, Vol. $51 \quad$ No. $1, \quad$ pp. $63-82$. https://doi.org/10.1108/00251741311291319

Fornell, C., \& Larcker, D. (1981). Evaluating Structural Equation Models with Unobservable Variables and Measurement Error. Journal of Marketing Research, 18(1), 39-50. doi:10.2307/3151312

Friestad, M., \& Wright, P. (1994). The Persuasion Knowledge Model: How People Cope with Persuasion Attempts. Journal of Consumer Research, 21(1), 1-31. Retrieved from http://www.jstor.org/stable/2489738

Goh K S and Balaji M S (2016). Linkıng green skepticism to green purchase behavior, Journal of Cleaner Production, 131:629-638, DOI: 10.1016/j.jclepro.2016.04.122

Grewal, R., Cline, T.W., \& Davies, A. (2003). Early-Entrant Advantage, Word-of-Mouth Communication, Brand Similarity, and the Consumer Decision-Making Process, Journal of Consumer Psychology, 13(3), 187- 197, DOI:10.1207/s15327663jcp1303_01

Hur, W., \& Kang, S. (2012). Interaction effects of the three commitment components on customer loyalty behaviors. Social Behavior and Personality: An international journal, 40, 1537-1542.

Keller, K. (1993). Conceptualizing, Measuring, and Managing Customer-Based Brand Equity. Journal of Marketing, 57(1), 1-22. doi: $10.2307 / 1252054$

Keller K. L. (1998) ,"Branding Perspectives on Social Marketing", in NA - Advances in Consumer Research Volume 25, eds. Joseph W. Alba \& J. Wesley Hutchinson, Provo, UT : Association for Consumer Research, Pages: 299-302.

Keller, K.L. (2001). Building customer-based brand equity: a blueprint for creating strong brands, Working Paper, Report No: 01-107

Lane, V., \& Jacobson, R. (1995). Stock Market Reactions to Brand Extension Announcements: The Effects of Brand Attitude and Familiarity. Journal of Marketing, 59(1), 63-77. doi:10.2307/1252015

Low, G. \& Lamb, C. (2000), "The measurement and dimensionality of brand associations", Journal of Product \& Brand Management, Vol. 9 No. 6, pp. 350-370. doi.org/10.1108/10610420010356966

Leonidou C. N. \& Skarmeas D. (2017). "Gray Shades of Green: Causes and Consequences of Green Skepticism," Journal of Business Ethics, Springer, vol. 144(2), pp. 401-415

Matthes J. \& Wonneberger A. (2014). The Skeptical Green Consumer Revisited: Testing the Relationship Between Green Consumerism and Skepticism Toward Advertising, Journal of Advertising, 43:2, 115-127

Mohr, L.A., Eroglu. D. \& Ellen,S.P.(1998) 'The development and testing of ameasure of skepticism toward environment claims in the marketers'communications'. The Journal of Consumers Affairs, 32(1) (summer),30-55.

Ng, P. F., Butt, M. M., Khong, K. W. \& Ong, F. S., 2014. “Antecedents of GBE: an integrated approach", Journal of Business Ethics, Vol.121 No.2, pp.203-215.

Obermiller C., Spangenberg E. \& MacLachlan D. L. (2005) AD SKEPTICISM: The Consequences of Disbelief, Journal of Advertising, 34:3, 7-17, DOI: 10.1080/00913367.2005.10639199 
Obermiller C. \& Spangenberg E. (1998). Development of a Scale to Measure Consumer Skepticism Toward Advertising, , Journal of Consumer Psychology, 7(2), 159-186

Parguel B, Moreau F. B. \& Larceneux F. (2011) How Sustainability Ratings Might Deter "Greenwashing": A Closer Look at Ethical Corporate Communication, Journal of Business Ethics, Springer Verlag, 102 (1), pp.15-28

Pelham, B. W. (2018). Not in my back yard: Egocentrism and climate change skepticism across the globe. Environmental science \& policy, 89, 421-429.

Pirsch J, Gupta S. \& Grau S.L. (2007). A Framework for Understanding Corporate Social Responsibility Programs as a Continuum: An Exploratory Study, Journal of Business Ethics, 70:125-140, DOI 10.1007/s10551-006-9100-y

Raska, D. \& Shaw, D. (2012). "When is going green good for company image?", Management Research Review, Vol. 35 No. $3 / 4$, pp. $326-347$. https://doi.org/10.1108/01409171211210190

Rahman, I., Park, J., \& Chi, C. G. Q. (2015). Consequences of “greenwashing" Consumers' reactions to hotels' green initiatives. International Journal of Contemporary Hospitality Management, 27(6), 1054-1081.

Romani, S., Grappi, S., \& Bagozzi, R. P. (2016). Corporate socially responsible initiatives and their effects on consumption of green products. Journal of Business Ethics, 135(2), 253-264.

Schreiber, J. B., Nora, A., Stage, F. K., Barlow, E. A., \& King, J. (2006). Reporting structural equation modeling and confirmatory factor analysis results: A review. The Journal of educational research, 99(6), 323-338.

Shrum L. J., McCarty J. A. \& Lowrey T. M. (1995). Buyer Characteristics of the Green Consumer and Their Implications for Advertising Strategy, Journal of Advertising, Volume 24, Issue 2, Pages 71-82

Singh, S., Vrontis, D., \& Thrassou, A. (2011). Green marketing and consumer behavior: The case of gasoline products. Journal of Transnational Management, 16(2), 84-106.

Simon, C., \& Sullivan, M. (1993). The Measurement and Determinants of Brand Equity: A Financial Approach. Marketing Science, 12(1), 2852. Retrieved from http://www.jstor.org/stable/183736

Skarmeas D. \& Leonidou C. N. (2013) When consumers doubt, Watch out! The role of CSR skepticism, Journal of Business Research, 66, pp. 1831-1838.

Srivastava R.K. \& Shocker A.D. (1991) Brand equity: a perspective on its meaning and measurement, Report (Marketing Science Institute), no. 91-124.

Ulusoy, E. \& Barretta, P. (2016), "How green are you, really? Consumers' skepticism toward brands with green claims", Journal of Global Responsibility, Vol. 7 No. 1, pp. 72-83. https://doi.org/10.1108/JGR-11-2015-002

Wei, C. F., Chiang, C. T., Kou, T. C., \& Lee, B. C. (2017). Toward sustainable livelihoods: Investigating the drivers of purchase behavior for green products. Business Strategy and the Environment, 26(5), 626-639.

Yoo, B., \& Donthu, N. (2001). Developing and validating a multidimensional consumer-based brand equity scale, Journal of Business Research 52(1):1-14, DOI: 10.1016/S0148-2963(99)00098-3 
Appendix 1: The Results of Convergent Validity analysis

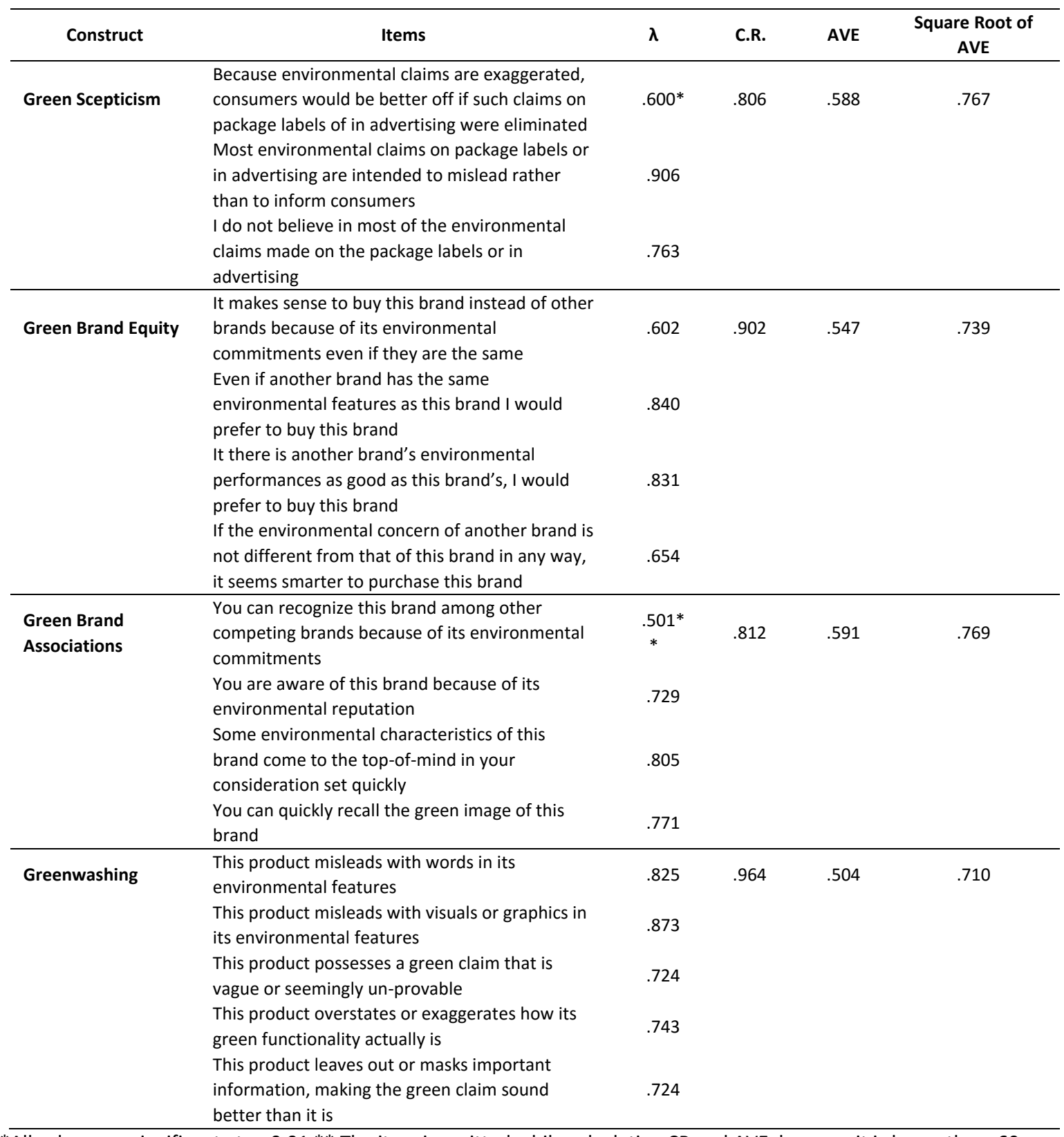

${ }^{*}$ All values are significant at $p<0.01 * *$ The item is omitted while calculating CR and AVE, because it is lower than .60 